University of South Florida

DIGITAL COMMONS

Digital Commons @ University of

@ UNIVERSITY OF SOUTH FLORIDA

South Florida

1996

\title{
Finding Our Inner Voices: Rediscovering Scholarship
}

Joseph M. Moxley

University of South Florida Department of English, moxley@usf.edu

Follow this and additional works at: https://digitalcommons.usf.edu/eng_facpub

\section{Scholar Commons Citation}

Moxley, Joseph M., "Finding Our Inner Voices: Rediscovering Scholarship" (1996). English Faculty

Publications. 135.

https://digitalcommons.usf.edu/eng_facpub/135

This Article is brought to you for free and open access by the English at Digital Commons @ University of South Florida. It has been accepted for inclusion in English Faculty Publications by an authorized administrator of Digital Commons@ University of South Florida. For more information, please contact digitalcommons@usf.edu. 
Centra, J. A. (1994). The use of the teaching portfolio and student evaluations for summative evaluations. The Journal of Higher Education, 65 (5), 555-570.

Clark, S. M., Corcoran, M., \& Lewis, D. R. (1986). The case for an institutional perspective on faculty development. The Journal of Higher Education, 57 (2), 176-195. spective on faculty developer Drucker, P. F. (1990, May-

Ewell, P T (1987) Establishing a campus-based assessment program. in D. F. Halpern [ed.]. New directions for higher education: Student outcomes assessment: What institutions stand to gain (59). pp 9-24. San Francisco: Jossey-Bass.

Gardner, H. (1983). Frames of mind: The theory of multiple intelligences. New York Basic Books.

Gardner H. (1993). Multiple intelligences: The theory in practice. New York: Basic Books.

Hahn R. (1990, September/October). What we talk about when we talk about teaching Change, 22 (5), 44-49.

Hutchings, P. \& Marchese, T. (1990, September/October), Watching assessment: Questions, stories, prospects. Change, $22(5), 12-38$

Jacobson, R. L. (1985, July 31). New Carnegie data show faculty members uneas about the state of academe and their own careers. The Chronicle of Higher Education, 30 (22), 25-28.

McKearion. The Journal of Higher Education, 53 (4), 460-464.

Mernam there be enough teachers? American Economic Review, 79, 242-246.

Sacken, D. M. (1990), Taking teaching seriously. The Journal of Higher Education, 61 (5), 548-564.

Seldin, P. (1991). The teaching portfolio: A practical guide to improved performance and promotion/tenure decisions. Bolton, MA: Anker Publishing Co., Inc

Westling J. (1988 October 19). The assessment movement is based on a misdiagnosis f the malaise afflicting American higher education. The Chronicle of Higher Education, $35(8), \mathrm{B} 1, \mathrm{~B} 2$.

\section{Finding Our Inner Voices: Rediscovering Scholarship}

Joseph M. Moxley

ABSTRACT: This essay explores the need to reconsider how we define, reward, and support scholarship, and the philosophical foundation of what a scholar really is Noting that only 10 to $15 \%$ of the professoriate regularly publish, the author questions if some faculty become stymied and distanced from their work because of the gap that exists between what they want to do and what their institutions expect them that Could more faculty find their voices as scholars and public intellectuals if univers to and colleges ascribed more value to the scholarships of teaching The surprising results of a survey of members of the Professional and Organizational Development Network in Higher Education are included.

\section{Introduction}

The landslide of recent essays and books about the need to redefine scholarship suggests that changes to the faculty reward system are truly imminent. Critics of higher education argue that we need to broaden our conception of scholarship so that we support a greater range of creative endeavors. According to Boyer (1990) and Rice (1991), for example, the existing faculty reward system places too great an emphasis on the scholarship of discovery and too little emphasis on the scholarships of integration, teaching, and application (or practice). Rather than only valuing basic, theoretical research, Boyer and Rice argue that universities should also value applied research, community service, and teaching. While these critics honor scholarship that discovers information, they point to the fact that the bulk of traditional scholarship and research remains uncited. For example, David Hamilton's (1991) analysis of $10 \%$ of all scientific journals published worldwide found that much scholarship is not

Joseph M. Moxley is professor of English at the University of South Florida. He has edited, authored, or co-authored seven books, including The Politics and Processes of Scholarship. He has published over thirty articles and stories and served as an editor for several academic journals. In 1994 and 1990, he received Florida Board of Regents' Awards for Excellence in Undergraduate Teaching. He offers academic writing workshops for faculty. 
cited: physics has about $37 \%$ uncited, medicine $46 \%$, mathematics $55 \%$, engineering $72 \%$, and social sciences $74 \%$.

While we clearly want to ensure that faculty have the academic freedom, time, and support necessary to discover knowledge, we should also view teaching as a form of scholarship, Boyer and Rice argue, because good teachers research their subjects. We should acknowledge the work of scholars who work as public intellectualsthat is, scholars who integrate information from a variety of disciplines and convey it to a variety of audiences. We should honor scholarship that applies to consequential problems, such as heart disease and acid rain. We should revise the faculty reward system so that it acknowledges the work of faculty who grapple with pedagogical, social, political, and moral issues, such as the failure of our schools to teach cultural, critical, or computer literacy; the deterioration of our environment; the population explosion; and, racism.

Strong forces, however, are obstructing our efforts to redefine scholarship to account for a broader range of creative endeavors. Since the 19th century, when American universities and colleges adopted Germany's faith in the ideal of pure research, the legacy of privileging "pure" theory/research over applied research and pedagogy has guided the research missions of colleges and universities. As a result of this tradition, tenure and promotion committees may often devalue research that integrates and synthesizes theories across disciplines. These committees tend to discount trade books, textbooks, and pedagogical articles. They may kowtow to the scholar whose work is read by under fifty specialists, yet deride the scholar whose work is read by thousands and discussed in popular newspapers and magazines.

As members of the academic culture, we tend to prize scholarship most when it is rooted in the scientific method and written in technical jargon decipherable only by specialists. In a naive move toward objectivity (which is clearly a rhetorical construct), we expect scholars to eschew the first person, to write in the institutional passive, and to hide the role of ambiguity, change, and synchronicity in so-called "hard" research. Clearly, given the long shadow of these traditions, we cannot expect to quickly alter the intellectual climate of our campuses.

In this essay, I explore the need to reconsider how we define, reward, and support scholarship. I explore the philosophical foundation of what a scholar really is and should be. I also review the results of a survey that I submitted to members of POD, the Professional and Organizational Development Network in Higher Education, which is composed of faculty-development specialists. Because POD members tend to hold faculty-development positions within academe-such as associate provost, dean of Faculty Development, or coordinator of Teaching Enhancement Centers-I expected to receive "pro-change" results. However, as described below, the results I gained from this survey are quite surprising.

\section{Why do We Need to Change the Faculty Reward System?}

Ernest Boyer (1990), Gene Rice (1991), Robert Diamond (1994), and other distinguished critics of higher education are challenging universities and four-year colleges to reconstruct their conception of scholarship as "pure" and to reconsider their perception of undergraduate teaching as a theoretical. These critics have faulted academic institutions for favoring a narrow range of intellectual pursuits. Boyer's Scholarship Reconsidered (1990) and many recent articles in academic and trade journal suggest that faculty believe their institution's narrow conception of scholarship undermines their desire to conduct applied research or professional service. When Peter Gray, Robert Froh, and Robert Diamond (1994) surveyed " 45,000 faculty, chairs, deans, and administrators at 47 research universities," the 23,300 responses that they received led them to conclude that "there [is] a desire for a greater balance between research and teaching." Additional results are as follows:

- Most members of all groups (both faculty and administrative groups) indicate that their institution should favor an equal balance between research and undergraduate teaching.

- Most faculty (68\%) see their institution favoring research over teaching, with the majority of faculty (55\%) seeing their institution very strongly favoring research over teaching.

- Faculty in particular perceive that the higher one's position in the university administration, the greater one's bias toward research.

- Each administrative group (academic unit heads, deans, offices of academic affairs) sees both faculty and other administrative groups favoring a balance between research and teaching. (Gray et al., 1994, p. 3)

My experience as a composition specialist, as someone who visits college and university campuses to provide academic writing workshops for faculty, suggests that some faculty feel blocked by their in- 
stitution's conception of scholarship. Instead of listening to their inner voices, their own gut responses to academic literature about what to create, some faculty become stymied, distanced from their work, because of the gap that exists between what they want to do and what their institutions expect them to do. Rather than feeling free to chase the random idea, to pursue topics as they evolve during composing, some faculty become silenced, reluctant to research and publish articles unrelated to their dissertation specialization, and apathetic about conducting the scholarship that their department values. Of course, we can identify many other reasons for not conducting scholarship, such as the tendency to procrastinate, financial obligations, parental responsibilities, negative attitudes about scholarship, self-defeating thinking about one's authority and potential, the lack of mentors, and the failure of some universities to nurture professors' and graduate students' apprenticeships as writers, researchers, an agents of change. Yet, because one's selection of a topic is so fundamental to the creative enterprise, it seems reasonable to wonder whether more faculty would cast off their role as technicians and become producers of knowledge if they felt empowered-and appreciated-for pursuing topics related to teaching or applied problems. Present estimates of productivity tend to suggest that only 10 to $15 \%$ of the professoriate regularly publish (Jalongo, 1985; Sykes, 1988; Boice \& Jones, 1988), so we surely need to consider the possibility that ascribing more value to the scholarships of teaching, practice, and service will encourage more faculty to find their voices as scholars.

The calls to reform the faculty reward system are not limited to a few isolated critics. Professional organizations; postmodern theories, composition theory; environmental, social, moral, and economic problems outside of academe; and the emergence of new technologies-these sites of economic and intellectual struggle are invigorating our need to broaden our conception of scholarship to account more adequately for the creative activities of productive faculty. Forces are coalescing to promote systematic change in the definition and reward of scholarship.

\section{Who and What Are the Agents of Change?}

\section{Professional Organizations are Advocating Change}

The Institutional Priorities and Faculty Rewards Project, which Robert Diamond directs at Syracuse University, has been working with dozens of major academic organizations to draft position statements that colleges and universities can employ to judge more accurate the creative endeavors of faculty (Diamond, in press). While the immediate effect of these positions may be questionable, eventually, as these position statements are promulgated and discussed by administrators and faculty members, they surely will influence the tenure and promotion decisions made at colleges and universities throughout America.

The Postmodern Conception of Scholarship Supports Changes to the Faculty Reward System

Thanks to a variety of postmodern philosophies-such as, social constructionism, deconstruction, antifoundationalism, feminism, critical literacy, and liberatory learning pedagogy-many academicians have rejected the modernist's faith in objectivity and have challenged traditional notions of scholarship as the objective illumination of the truth; many academicians have embraced the concept of multiple truths, of situational knowledge, and of valuing the striving for truths over the expectations of uncovering a truth that transcends culture and the evolution of time and knowledge. By validating the subjective nature of interpretation, postmodern theories have provided the theoretical ground for qualitative research methodologies and the personal essay. Because postmodernism challenges the positivistic backbone of traditional scholarship, it is likely to retain its energizing force in redefining faculty priorities.

The Process Model of Scholarship Supports Changes to the Faculty Reward System

While postmodern philosophies, with their antifoundational, phenomenological stance, have fueled the fire for a broader conception of scholarship, the recent work of composition theorists and facultydevelopment specialists also feeds the fires of change. University administrators have begun to realize that faculty do not receive the training they need in graduate school to write regularly, to market their research, to understand the generative role of writing, and to understand thinking/writing connections. As a result, many universities and colleges are now providing academic writing workshops for faculty and graduate students across disciplines. These workshops empower non-publishing faculty to cast off their roles as technicians 
and become producers of writing by helping them understand and experience writing as a generative, thought-provoking process, by shattering myths that prevent faculty from writing, and by familiarizing faculty with effective composing and marketing habits.

Over the past decade, compositionists and faculty development theorists have written numerous books designed to help faculty find their voices as scholars and researchers (Boice 1990; Schoenfeld \& Magnan, 1992; Moxley, 1992a, 1992b). Strategies can be identified (Moxley \& Lenker, 1995) to enable faculty to find their voices as scholars, researchers, and grant writers. As progressive institutions play a more active role in helping faculty develop their research, writing, and publishing skills, more faculty will realize their potential as researchers, scholars, and teachers, which will inevitably stretch the boundaries of existing scholarship, research, and graduate training.

\section{The Utilitarian Conception of Scholarship Supports Changes to the Faculty Reward System}

Because academics at colleges and universities are rewarded for conducting theoretical and quantitative research for specialists, rather than for teaching or for synthesizing research for general and professional audiences, much academic work has been depicted in newspapers, popular magazines, and academic forums as self-indulgent, impenetrable, and meaningless. The trend toward specialization is irrefutable, and nowadays some scholars and editors pride themselves in producing scholarship that few readers can understand. If this trend continues, some critics, such as Patricia Limerick (1993), predict it will lead to the death of scholarship: "...universities and colleges are currently embattled, disturbed by the public and state funding institutions. As distressing as this situation is, it provides the perfect timing for declaring an end to scholarly publication as a series of guarded conversations between professors" (p. 23).

The need for us to consider the practical dimensions of our work will surely become more apparent as we face additional social, educational, environmental, and technological problems. Racism, drug abuse, random violence-these are examples of real problems that have grown exponentially in the past few decades. Eventually, if we want to keep students in our classes, we must confront these problems. Accordingly, we must reject the simplistic assumption that "pure theory" should be privileged over scholarship that synthesizes others' theories or scholarship that applies to practical problems.

\section{Creation of a New Electronic Frontier in Cyberspace Inspires} Changes to the Faculty Reward System

Recent technological developments-desktop publishing programs, network computers, hypertext, and hypermedia programs-provide a new intellectual frontier. Because the computer changes the way we think, socially construct meaning, and present our thoughts, we can anticipate entirely new methods of research and new scholarly products. Innovative hypertexts and multimedia programs are already transforming scholarship.

Hypermedia programs, which blend the visual and audio qualities of television with the more interactive qualities of instructional software, enable faculty and students to escape the linear progression of the traditional book. By highlighting hot words-that is, hypertext links-readers can choose their reading path and sometimes even add text to the hypertext. According to James Lichtenberg (1994), we can expect to see more ancillary multimedia packages shrink wrapped with traditional textbooks-test banks, video-discs and CD ROM discs. Present research suggests that students are excited by multimedia presentations, and, of course, these formats involve additional learning modalities. Once libraries and university faculty have the necessary hardware, faculty may consider the process of waiting a year to produce a book in bound form to be wasteful and unnecessarily time consuming. Eventually, I believe the hypertext writing space will be the preferred mode of expression by contemporary and emerging authors. In time, most of us will have our syllabi, research notes and essays available via hypertext links to our homepages on the World Wide Web.

However, the weight of tradition and the expense of retraining and retooling academe has kept many from exploring the parameters of virtual reality. Presently, because professors are not receiving credit for developing instructional software, for establishing and maintaining listservs for scholarly conversations, or for writing hypermedia programs, innovation is more likely to come from graduate students, nontenured professors, and people on the fringes of academic culture (LeBlanc, 1994b). Although the computer has been available for nearly two decades, many faculty still do not use word processors to compose, desktop publishing and graphics programs to prepare books in cam- 
era-ready format, presentation software to polish their lectures, hypertext programs to respond to student writing, or electronic grade books to ease the computation of grades. When the Office of Scholarly Communication and Technology of the American Council of Learned Societies (ACLS) received 3,000 responses from professors who worked in different academic disciplines-literature, classics, philosophy, history, linguistics, political science, and sociology-it found that faculty are surprisingly reluctant to employ technology to increase access to information and to improve their efficiency (Jones, 1994):

By 1985, 98\% of respondents used computers routinely. Of academic respondents who used computers in their work, $95 \%$ used them for word processing, but only $17 \%$ used computers to access the library's online catalog. According to $59 \%$ of the respondents in research universities, part or all of their library's catalog was computerized, but $38 \%$ of the respondents working in research universities who answered a question on computerized catalogs reported never having used the catalog .... [O]nly $22 \%$ had had database searches conducted once or twice, and $13 \%$ had used this service several times, but only $5 \%$ had used it frequently. Another $7 \%$ did searches themselves, but only $6 \%$ of respondents in research universities said that material identified through database searches were of great importance to them. (pp. 162163)

Clearly, it is curious and worrisome that so few faculty-whose jobs dictate researching and publishing to avoid perishing-are reluctant to employ technology. Similar indicators that faculty are not experimenting with communication technologies were recently reported in a study paraphrased in an MBU (Megabyte University Listserv) post:

The annual University of Southern California National Survey of Desktop Computing in Higher Education is out, and results show that only a small percentage of college courses use technology to enhance or supplement instruction. Similarly an Association of American Publishers survey shows only $2 \%$ of college professors reporting that their assignments require the use of software, and only $9 \%$ of courses use e-mail for instructor-student communications. (Siering, 1995, p. 1)

However, as A. L. Shoaf (1994) recently remarked, multimedia software and the Internet are shattering the foundations of traditional scholarly discourse. Thanks to the Internet, where one works or studies will no longer be so important in creativity. Faculty and graduate students will have greater access to scholarly dialogue and disciplinary boundaries will be broken. Because e-mail tends to flatten traditional hierarchies-that is, because communication flows without the niceties of letterhead and formal titles-people can talk with others who would otherwise be inaccessible. In 1994, 52 nations were added to the 67 nations that already participated in the Internet network. In January 1994, 54 billion packets of data were exchanged on the Internet. Presently, there are 20-30 million Internet users and 14,000 networks, and current predictions are that this number will expand by $400 \%$ per year (Shoaf, 1994). Increasingly, we will see more academic publications published in electronic as well as printed form. For example, in 1994 Johns Hopkins introduced Project Use, which involved placing the entire contents of Hopkins journals on the Internet (Shoaf, 1994).

According to Paul LeBlanc, scholarship becomes a verb as opposed to a noun on the Internet (1994a). Rather than static texts, future scholarship can take the form of real-time dialogues. For example, 400 physicists shared comments and co-authored a report on the Internet. At Texas Instruments, teams of technicians in New York pass their ideas about a project on to London, so another team can immediately begin takling the same project. At the close of day in London, a third team picks up the project in Hong Kong and works on it until the New York office is back on the job (LeBlanc, 1994a). Perhaps in the days ahead students from different colleges will use the Net to collaborate together on applied research projects.

Soon our students (and their parents) will expect professors to establish listservs for their classes. Rather than research topics in the library, our students will find appropriate bulletin boards to post their queries and ideas. In time, our students will not even consider submitting essays without visuals, and their oral presentations will be slick, multimedia affairs. Perhaps students will be expected to author their final reports via html (hypertext mark-up language) and then publish their work on the World Wide Web.

Plummeting prices in computer hardware should result in more computers entering classroom settings. While the ratio of computers to students was 92:1 in 1983, it was 31:1 in 1993 (LeBlanc, 1994b). As the market expands for these innovative products, our nation's faculty will be challenged to take a leadership role in developing innovative software. After all, our nation's faculty possess the pedagogical expertise that software development specialists need to design effective multimedia and interactive instructional software.

Clearly, under the present reward system, tenure and promotion committees are unlikely to value a faculty member's efforts to establish productive listservs, electronic journals, or hypermedia programs. 
In this late age of print, as Jay Bolter (1991) likes to call our current times, contemporary scholars cling to what are quickly becoming outdated notions of intellectual property. Traditionally, we spend a lot of our time packaging the parameters of our ideas, securing copyright, finding funding to pay for permissions. But as James Lichtenberg (1994) wisely remarked in a plenary address to The Politics and Processes of Scholarly Publishing Conference, Once it's digitized, it's got legs" (1994). Likewise, in the context of academe, I think we will soon will be saying, "Once it's digitized, it's got the Power." In other words, what's valued in the global context-scholars throughout the world bouncing ideas off satellites-must transform the classroom and academic disciplines. As responsible teachers, we cannot ignore the fact that all of the major disciplines our students will labor in for much of their lives-such as the business and medical disciplines-require students to organize thoughts with the aid of computers. Although some may fantasize about the good old days of card catalogs and manual typewriters, faculty serving on tenure and promotion committees will eventually come to prize faculty members' use of computers in their research and teaching.

\section{Faculty Development Experts Are Promoting Change}

Clearly, there's a lot of talk and excitement about changing the faculty reward system. At a recent conference in scholarly publishing at the University of South Florida, for example, the presenters and respondents appeared to be in agreement that changes need to take place. And yet, not everyone wants to change the faculty reward system. After all, as Morton Winston (in press) argues in The Politics and Processes of Scholarship, those who are most empowered to alter the reward system-senior research professors, established editors, distinguished chairs-have most to lose by changing the reward structure. In turn, a graduate student-who must compete with as many as 200 others for a tenure-track, assistant professor position-must keep focused on the existing reward system: a record of scholarship that purports to break new ground keeps you ahead of the pack.

To gain some insight into the likelihood of real changes occurring any time soon in higher education, I surveyed 400 members of the POD (Professional and Organizational Development Network in Higher Education) at four-year colleges and universities (see Appendix). As expected, the survey results suggest that positive movements to redefine scholarship are occurring on campuses throughout Amer- ica. The results, however, also indicate that barriers still exist to adjusting the faculty reward system so that it more aptly accounts for faculty's creative endeavors. Although most of the 41 respondents who completed the survey support the recent calls for changes to the faculty reward system, they disagree about whether or not faculty should pursue their own intellectual passions or bow to the will of department and college-level tenure and promotion committees. Also, these experts differ regarding the degree and kind of support programs their universities offer graduate students, pre-tenure faculty, and mid-career faculty. While some faculty only have one grant writing workshop offered annually, others have full menus of opportunities to choose from, such as learning communities, writing across the curriculum programs, and workshops on academic writing, teaching, statistical procedures, and desktop publishing.

When we look at the average ranking respondents' assigned to the scholarships of discovery, integration, application, and teaching, we get the results that existing literature would lead us to expect. As illustrated in the Appendix, $44 \%$ of the POD members agree that the scholarship which discovers information is privileged over other forms of scholarship at their institutions. However, this average percentage hides the considerable variance found in each respondent's ranking of what goes on at his or her institution. For instance a few respondents gave "scholarship that discovers new information" zero points, while others assigned zero points to "scholarship that addresses teaching concerns" and "scholarship that integrates information."

The differences among faculty regarding the forms of scholarship they value were frequently illustrated in the respondents' prose comments. For example, a few respondents were skeptical about what one calls the "blathering about the need to redefine scholarship to include teaching." An associate vice president of Academic Affairs at a large private university remarked, "It is a fatal mistake, in my judgment, to redefine scholarship so broadly. All important distinctions are lost. More traditional scholarship may simply redefine itself as separate and better." A coordinator of Faculty Development at a mid-sized university in Illinois also questioned whether redefining teaching as a form of scholarship will change the underlying assumptions that now privilege research even at small liberal arts colleges: "We say teaching is the most important factor in tenure and promotion decisions, but in fact publication is the determining factor again." Even at "teaching" (as opposed to research) institutions, greater prestige is enjoyed by the researcher. In turn, a faculty-development spe- 
cialist at Stanford wrote, "My guess is that the integration of which Ernie Boyer speaks will be very slow in coming, and that its impact on research will be modest." Support for this professor's hunch is clearly found in the survey results. While a few of the respondents reported that teaching portfolios were becoming more popular on their campuses, $41 \%$ of the respondents believed it unwise for untenured professors or associate professors to spend more than $30 \%$ of their time engaged in teaching-related activities.

Nevertheless, at some campuses, teaching is becoming more important. For example, a graduate student instructor at the University of California at Berkeley, writes "There is much talk about teaching on the Berkeley campus. . . . The Academic Senate's Budget (read, "Personnel") Committee talks about the importance of being a good teacher for reasons of promotion." And Karron Lewis, the 1994-95 president of POD and the assistant director of the Center for Teaching Effectiveness at the University of Texas at Austin, reported in her response to my survey that:

Each department on campus should have a systematic method of evaluating the teaching of all its faculty. This systematic method should include, but not necessarily be limited to, the following: (a) student course evaluations; (b) peer review by faculty colleagues; and (c) exit surveys (or similar evaluations) from graduate students or recent alumni. Many departments are developing portfolio methods for evaluating teaching. Yet we still need to work on having the scholarship of teaching (e.g., publishing articles about teaching) "count" more in tenure and promotion decisions.

The survey responses indicate that obstacles still exist to changing the academic reward system. Nevertheless, many of these faculty development experts are taking a leadership role in redefining scholarship. For example, ten of the respondents noted that they have served on university department and college committees that have rewritten (or are in the process of rewriting) tenure and promotion guidelines to account for a more diverse conception of scholarship. Funds from the Lilly Foundation, the Bush Foundation, and FIPSE have encouraged Stanford University, Rider University, the University of Minnesota, Duluth, and the University of Nebraska-Lincoln to reexamine their processes of evaluating and rewarding teaching and scholarship. Several universities are looking forward to extended discussions on these issue at day-long, funded faculty retreats.

Although only 29 of the faculty development experts responded to the third short-answer question, an overwhelming $92 \%$ of these re- spondents agreed that their colleagues would be more inclined to write, research, and publish if institutions gave more weight to the scholarships of integration, application, or teaching during annual evaluations. For instance, Karron Lewis at the University of Texas at Austin wrote, "By including the scholarships of integration, application, and teaching during annual evaluations, additional outlets for faculty writing would develop and a wealth of information that now goes unwritten (because it isn't 'worth' the time spent on that kind of writing) might finally be shared."

While these faculty development experts almost unanimously agreed that broadening the parameters of scholarship will inspire more faculty to write, they disagreed about whether untenured professors or associate professors should change the existing academic reward system-that is, research and publish articles that are not supported by their home institutions. Forty-one percent answered "no" when asked, "Do you believe untenured professors or associate professors should conduct scholarship that they are most passionate about if this scholarship is not valued by their department, college dean, or provost?" Some of the respondents who believed candidates should focus on satisfying the desires of others did not perceive this question to relate directly to academic freedom. For example, a professor at a university in Nebraska wrote,

I don't see this as an issue of academic freedom. Rather, it is examining the departmental goals (set by faculty) and determining how each person relates to those goals. For example, our journalism college sees its goals as teaching/developing credible journalists and serving the profession of journalism. Research is not at issue when P/T [promotion/tenure] decisions are made.

In contrast, a professor from a small liberal arts college captured the spirit of those who favor following one's inner passion (rather than the direction of a tenure and promotion committee) when he asked, "How else will values be changed?"

The range of the respondents' comments and responses to survey questions suggests that differences exist between colleges, even departments, regarding how scholarship is defined, evaluated, and supported. From their descriptions of how their academic institutions reward scholarship, we can see that many of these people still work in a climate that does not value teaching or the scholarships of integration or application. Ultimately, the results of this survey are not dissimilar to the national survey results of Ernest Boyer's study reported in Scholarship Reconsidered or Peter Gray, Robert Froh, and 
Robert Diamond's (1992) survey of 23,300 faculty from 47 states: many faculty want to change the reward system under which scholarship is supported, evaluated, and rewarded, yet tremendous obstacles exist to actually implementing change. Surprisingly, faculty-even some faculty development specialists-lack the will to promote change on their campuses.

\section{Conclusion}

In our postmodern, networked, multicultural world, contemporary academics understand that scholarship is not conducted in a neutral space. We understand that our assumptions about what is good, what is possible, and what is valued are inscribed by our ideological positions (Berlin, 1988). Consequently, many of us have come to question who benefits when universities privilege the scholarship of discovery over the scholarships of teaching, integration, and application. (Those of us who have been in academe for a while know the short answer to this question: senior research professors who have mastered the publish or perish game, our distinguished colleagues who serve on the editorial boards of our prestigious journals, and journal editors have most to gain by maintaining the status quo.)

And yet, I do not wish to suggest that we should not honor the scholarship of discovery. Clearly, our disciplines, our world, run on the impetus of the creative spirit. Innovation is one of the primary engines that directs our disciplines, even our world economy. As researchers and scholars, we are eager to generously praise and reward faculty for making new discoveries. We understand our responsibility to contribute to the scholarship of discovery.

We also understand, however, that our students, our environment, and our culture are the losers when we privilege the modernist's myopic view of scholarship. When push comes to shove, we only have a few ways of knowing - teacher research, historical, speculative, hermeneutical, clinical, ethnographic, or empirical. And when you really look at the research that emerges from these methodologies, you see that theory and practice are always intertwined.

Most importantly, we need to recognize that our nation's faculty will become more involved in confronting and solving the problems that trouble our world if we value the scholarships of integration and application. As an example of what redefining scholarship would do to change our world, let us consider what would happen if faculty outside of the education college became involved in tackling major educational and social problems. Reflecting problems in our society at large, our schools are infected with racism, violence, and drug abuse, leading some to predict that additional inner cities will follow Los Angeles' lead and erupt in flames. Presently, our country "ranks 49th among the 158 members of the United Nations in measures of literacy; 25 million American adults cannot read a warning label and another 35 million have only marginal reading ability" (Faigley, 1992, p. 69). In urban districts where nonwhites constitute the majority, dropout rates of nonwhite children exceed $60 \%$. In New York City, this figure exceeds $70 \%$ (Fine as cited in Giroux, 1992). As Henry Giroux points out in his excellent summary of demographic statistics, this figure is particularly alarming when we recognize that Blacks constitute a majority in more than one third of our cities. While it is a national embarrassment that so many people remain illiterate, the violence that trails in the wake of this educational failure is more disturbing. According to a recent national survey, one in ten teachers and one in four students have been the victims of violence in the schools. Nor are our post-secondary schools insulated from the effects of our failure to educate our children. A recent National Assessment of Educational Progress (AAUW, 1992) found that only 5\% of the high school seniors tested possessed the skills necessary for technical or college level work, and it is not uncommon for as many as $60 \%$ of entering freshman to be placed in developmental English courses in post-secondary schools with rigorous entrance requirements. And although American colleges and universities have improved access to higher education for women and ethnic minorities, the completion rate of U.S. college students remains stubbornly stalled at approximately $60 \%$.

It is true, of course, that we are not solely responsible for the collapse of the family and the epidemic of violence and racism that undermines our efforts in the classroom. However, we are responsible for the ways we support and motivate scholarship. We should be concerned that the present reward system discourages faculty from realizing their potential and finding their inner voice as teachers and scholars.

\section{ACKNOWLEDGMENTS}

This essay emerged out of a four-day conference held at the University of South Florida in March of 1994. Accordingly, the author thanks the conference co-editor, Lagretta T. Lenker, and the sponsors 
of this conference: David Stamps, Rollin Richmond, Priscilla Pope, Richard Streeter, and William Heller. For extending thinking on the matters addressed in this essay, the author thanks R. Eugene Rice, Robert Diamond, Bob Boice, R. A. Shoaf, Paul LeBlanc, and Linda Sarbo.

\section{References}

AAUW Report. (1992). How schools shortchange girls. Washington: NEA Professional Library.

Boice, R., \& Jones, F. (1988) Why academicians don't write. Journal of Higher Education, 4(2) 41-46.

Boice, R. (1990). Professors as writers. Stillwater: New Forums Press, Inc.

Bolter, D. J. (1991). Writing space: The computer, hypertext, and the history of writing. New Jersey: Lawrence Erlbaum Associates.

Boyer, E. L. (1990). Scholarship reconsidered: Priorities of the professoriate. Princeton: The Carnegie Foundation for the Advancement of Teaching.

Berlin, J. A. (1988). Rhetoric and ideology in the writing class. College English 50, $477-494$

Diamond, R. M. (1994, May 11). The tough task of reforming the faculty-rewards system. Chronicle of Higher Education, pp. B1-B3.

Diamond, R. M. (1995). Disciplinary associates and the work of faculty. In J. M. Moxley \& L. Lenker (Eds.), The politics and processes of scholarship (pp. 19-26). Westport: Greenwood Publications.

Faigley, L. (1992). Fragments of rationality: Postmodernity and the subject of composition. Pittsburgh: University of Pittsburgh Press.

Giroux, H. (1992). Border crossings: Cultural workers and the politics of education New York: Routledge.

Gray, P. J., Froh, R. C., \& Diamond, R. M. (1992). A national study of research universities. Syracuse University: Syracuse University Center for Instructional Development.

Gray, P. G., Froh, R. C., \& Diamond, R. M. (1994). "Myths and realities." Institutional Priorities and Faculty Rewards Information Packet. Syracuse University: Center for Instructional Development.

Hamilton, David P. (1991, January 1). Research papers: who's uncited now? Science 251 , p. 25.

Jalongo, M. Renck. (1985, Winter). Faculty productivity in higher education. Educational Forum 49: 171-182.

Jones, W. G. (1994). Humanities scholars' use of computers. In L. S. Cynthia and S. Hilligoss (Eds.), Literacy and Computers (pp. 157-170). New York: MLA.

LeBlanc, P. (1994a, Mar. 13). Writing software. Paper presented at the politics and processes of scholarly publishing conference. Tampa, Florida.

LeBlanc, P. (1994b). The politics of literacy and technology in secondary school classrooms. In L. S. Cynthia and S. Hilligoss (Eds.), Literacy and Computers (pp. 2236). New York: MLA.

Lichtenberg, J. (1994, March 1). Protecting intellectual property. Paper presented at the politics and processes of scholarly publishing conference. Tampa, Florida

Limerick, P. N. (1993, October 31). Dancing with professors: The trouble with academic prose. The New York Times Book Review, pp. 3, 23-24.
Moxley, J. M. (1992a). Publish, don't perish: The scholar's guide to academic writing and publishing. Westport: Praeger.

Moxley, J. M. (1992b). Writing and publishing for academic authors. Lanham: University Press of America.

Moxley, J. M., \& Lenker, L. (1995) (Eds.). The politics and processes of scholarship. Westport: Greenwood Publications.

Rice, E. R. (1991, Winter). The new American scholar: Scholarship and the purpose of the university. Metropolitan University Journal, pp. 1-7.

Schoenfeld A C and Magnan, R. (1992). Mentor in a manual: Climbing the academic ladder to tenure. Madison: Magna Publications.

Siering, G. (18 January 1995). The Heller Report fwd. Available at mbu-1@unicorn.acs.ttu.edu. Forwarded from info@ivory.educom.edu.

Shoaf, R. A. (1994, March 1). Let's be really PC! personal computers, the internet, and future of learned journals. Paper presented at the politics and processes of scholarly publishing conference. Tampa, Florida.

Sykes, C. J. (1988). ProfScam: Professors and the demise of higher education. Washington, D.C.: Regnery Gateway.

Winston, M. (1995). Prospects for a re-valuation of academic values. In J. M. Moxley \& L. Lenker (Eds.) The politics and processes of scholarship (pp. 53-65). Westport: Greenwood Publications.

\section{APPENDIX}

\section{Rating/Multiple-Choice Questions}

1. How does your academic institution value the following activities in its annual evaluation of faculty members' scholarship?

(Please indicate the importance you believe your institution attaches to the following activities by allocating some percentage of 100 points to each activity. For example, if you think Activity 1 is twice as important as Activity 2, you should assign it twice as many points. Please allocate a total of exactly 100 points.)

\begin{tabular}{|l|l|}
\hline Average & Scholarly Activities \\
\hline Rating & \\
\hline $44 \%$ & \begin{tabular}{|l|l|}
\hline 1. Scholarship that discovers new information \\
\hline $19 \%$ \\
\hline $19 \%$ \\
\hline $18 \%$
\end{tabular} \\
\hline 2. Scholarship that integrates existing research \\
\hline 3otal: 100 points \\
\hline
\end{tabular}


2. Do you believe untenured professors or associate professors are unwise to spend more than $30 \%$ of their time engaged in teaching-related activities?

\section{$\underline{41 \%}$ Yes $\underline{59 \%}$ No}

3. Many faculty have difficulty negotiating the parameters of academic freedom. Do you believe untenured professors or associate professors should conduct scholarship that they are most passionate about if this scholarship is not valued by their department, college dean, or provost?

\section{$59 \%$ Yes $\quad \underline{41 \%}$ No}

\section{Short-answer Questions}

1. What mentoring programs or training sessions, if any, is your institution providing to help your faculty or graduate students achieve their research and writing goals?

2. What changes, if any, is your institution attempting to make with regard to how it assesses the scholarships of integration, application, or teaching?

3. Do you believe that faculty would be more inclined to write, research, and publish if institutions gave more weight to the scholarships of integration, application, or teaching during annual evaluations?

\section{Comprehensive Professional Development Plan for a College of Education}

\section{Nancy A. McKellar}

ABSTRACT. The professional development plan for a college of education and the process used to develop the plan are described to encourage and assist others to undertake similar projects. The committee that developed the plan first had to reach consensus on the purpose and nature of professional development. The plan was cited by the National Council for Accreditation of Teacher Education (NCATE) review team as one of the strengths of the college. Reflections on why the plan was successful and the next tasks to be implemented in the ongoing professional development program are discussed.

\section{Introduction}

Programs to enhance faculty careers have traditionally focused on professional development or on personal growth. Wheeler and Schuster (1990) argued that the long-term objective of such programs should be to coordinate the three areas of professional, personal, and organizational development into a systematic faculty development program. Colleges and universities with high faculty morale tend to have multifaceted faculty development programs (Austin, Rice, \& Splete, 1991)

From an administrative perspective, faculty development is a matter of protecting one's investment. Stice (1984) presented a cogent example of how a faculty member hired in 1983 and retired in 2020 would likely earn a total salary in excess of one million dollars, not including fringe benefits. Put in these terms, it is clear that universities and colleges have a vested interest in maintaining and improving the effectiveness of their faculty members.

Nancy A. McKellar is an assistant professor in the School Psychology Program Department of Administration, Counseling, Educational and School Psychology, at Wichita State University. She received her $\mathrm{MA}$ and Ph. in Psychology from Northern Illinois University. Her professional interests include curriculum-based assessment and interventions for school-aged children.

Portions of this article were presented at National Council of States (NCSIE) 17th Annual Conference, San Diego, CA, November 1992. 